
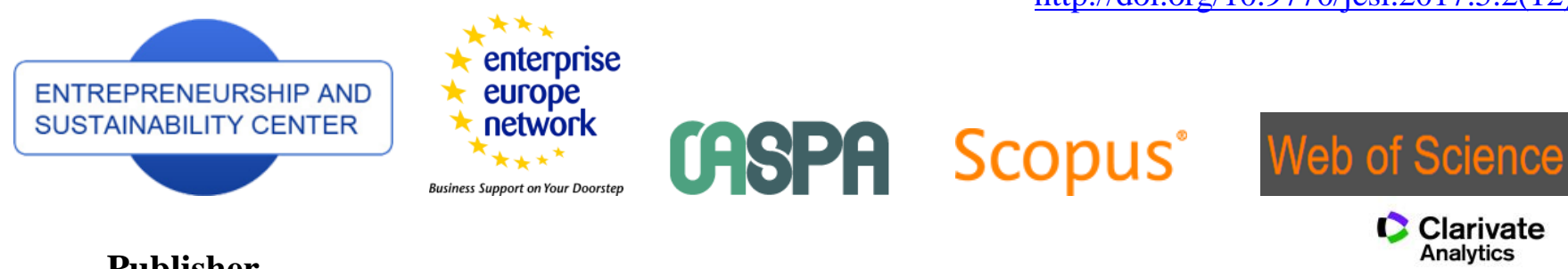

Publisher

http://jssidoi.org/esc/home

\title{
THE IMPACT ON THE POPULATION ON THE SUSTAINABLE URBAN ECONOMIC DEVELOPMENT
}

\author{
Inesa Pavlova ${ }^{1}$, Maija Šenfelde ${ }^{2}$ \\ ${ }^{1,2}$ Riga Technical University, 1 Kalku Street, Riga, LV-1658, Latvia \\ E-mails: $:^{1}$ Inesa.Pavlova@rtu.lv; ${ }^{2}$ Maija.Senfelde@rtu.lv
}

Received 25 August 2017; accepted 23 November 2017; published 29 December 2017.

\begin{abstract}
Today, attention is paid to urban sustainable development and a resident as of a sustainable urban economic development in the core and foundation and most problem is the migration of them. It's important to remember that the city is the socio-economic development and improvement of local promoter based resident. Given that both in Riga and in the whole country's population is shrinking, which is based on the migration problem. Riga is the largest and one of the economically richest municipalities and the capital of country in same time, it should serve as a model as a prop adjacent municipalities. It is important to remember and to follow Riga's sustainable development strategy according 2030 guidelines, which states that every neighborhood has equal opportunities to grow, develop and live, but is not currently being met. Given that the average active economically population is $62 \%$ of the employed population and $46 \%$ of the total population, which is critical in the city and surrounding sustainable development. Therefore, within the framework of the article it will be considered as a resident of the city affects urban sustainable economic development and will highlight the city of Riga overall economic performance and each residential area separately. The article is to determine what the impact of urban resident urban sustainable economic development is, and what the stumbling block of the population migration and low participation in urban development is, which is considered as one of the most important promoters of sustainability.
\end{abstract}

Keywords: urban environment, sustainable development, Riga, resident, economic development

Reference to this paper should be made as follows: Pavlova, I.; Šenfelde, M. 2017. The impact on the population on the sustainable urban economic development 5(2): 330-344. http://doi.org/10.9770/jesi.2017.5.2(12)

JEL Classifications: R11, R58

\section{Introduction}

There is a lot attention paid to regional sustainable development facets in the contemporary scientific literature (e. g. Menshikov et al. 2017; Bilan et al. 2017; Zemlickiene et al. 2017; Tvaronavičienė, Razminienė 2017;

Tvaronavičienė, Gatautis, R. 2017; Kendiukhov, Tvaronavičienè 2017; Štiglic 2017; Lincényi, Fabuš. 2017).

In this paper sustainable development Riga will be tackled. The following approach is adopted: it is assumed that one of the keys to the sustainable economic development of the Riga city is a Rigan and his/her awareness of affiliation to his/her living environment and the opportunities offered by it (Riga Development Program 20142020; Riga Sustainable Development Strategy till 2030). This is important because in the future it would improve 
the situation in the city as a whole, reducing the demand for movement to other cities to receive services that are not available in his/her own city.

One of the main reasons for the migration of residents to the neighbouring cities of Riga is the well-organized environment and difference in apartment prices. Of course, every ambition can not be met and satisfied, but when analysing the characteristics of the city of Riga, it can be concluded that the inequality in the city is obvious. One person has the opportunity to develop and have a good rest in the locality of his own, while the other is deprived of this opportunity; then the question is why there is such an inequality. An example is Mezciems, where the number of pre-school educational establishments is smaller than in Skanste, where the number of population is 10 times smaller. Whereas, when researching cultural institutions in the neighbourhood, an incomprehensible spectacle appears; cultural institutions are not available in the larger localities of the city, but in Bukulti, which has 600 residents, there is a cultural center, but in Ziepniekkalns, which has 33 thousand residents, there is no cultural centre, the same spectacle also opens up in Purvciems. Brasa, where residents are three to four times fewer than in Purvciems and Ziepniekkalns, has four cultural institutions. Of course, within Riga you can go to nearby localities or the center, where there are almost a hundred of cultural institutions. However, in order the residents would have opportunity to develop and creatively improve in their locality, a cultural institution is often the place, where various events for children, adults and elderly people are organized, in order the resident could participate and feel comfortably in his/her locality and the city as a whole and he/she has the opportunity to attend some beautiful cultural and educational event and feel that he/she belongs to it. Further, in this research, the general characteristics of the city, the structure and characteristics of the population will be dealt with. The local government budget will be explored and analysed to determine the impact of the resident on the sustainable urban economic development.

\section{Genetal characteristics of the city}

Riga has 58 localities and each locality is different, each has its own history and story of its origin, for example, Plavnieki is a locality, where in the past there was only a meadow and developed agriculture, while Kengarags was "plunged" from the depths of the water. Therefore, the localities of the city are different and varied, because the history of their origins is also different and each locality has its own identity and character. The total area of Riga is $307.17 \mathrm{~km}^{2}$ with population of 641 thousand (Main demographic indicators).

Riga, as the capital of the country and the largest city in the Baltics, plays an important role in the development of the state of Latvia, influenced both by it's the historical movement and the favourable geographical location. Undoubtedly, Riga must take on the organization of various national and international events, care for the welfare, health and education of the residents of Riga and Latvia, as well as contribute to the promotion of the national economy.Riga was founded in 1201, at that time there were no such administrative localities, only the central part of Riga, which is Old Riga and Citadele, was developed. In Riga at that time, there were only about 1 thousand residents. Historically, the surrounding areas were farmland, where manors and villages were located. Because of various military conflicts, life in the suburbs of Riga was unsafe and unpredictable. Riga was burned up many times (Bakule, Siksna 2009; Rubins 2004)

Since the year 1559, cases of burning up had been already repeated seven times, and in 1812, Riga was hurriedly burned up, because it was suspected that Napoleon would attack, but he chose a different direction and passed Riga. These historical facts also appear in the architectural building in the central part of the city, where wooden houses dominate. Riga was restored with the help of various architects and at various stages of government (Bakule, Siksna 2009). 
During the elimination of war consequences, new residential houses were almost not built. Only in the late 1940s, the first houses for workers were built. Such block was formed in Riga. Given that Riga has the developed industry, the number of population rapidly increased every year and in the late 1950s the apartment issue was solved and massive city building was started (Kreituse et al. 2009).

As previously mentioned, one of the foundations of the sustainable economic development of the city is its resident. Unfortunately, in general, the statistics show negative trends, as the number of population in the city of Riga is decreasing. In 2017, the statistical indicators are more positive, as the number of population increased by more than 2 thousand people, but to reach indicators of 2007, a long way is still to go. (See Figure 1).

One of the keys to the sustainable economic development of the city is a Rigan and his/her awareness of affiliation to his/her living environment and the opportunities offered by it (Riga Development Program 20142020; Riga Sustainable Development Strategy till 2030). This is important because in the future it would improve the situation in the city as a whole, reducing the demand for movement to other cities to receive services that are not available in his/her own city.

One of the main reasons for the migration of residents to the neighbouring cities of Riga is the well-organized environment and difference in apartment prices. Of course, every ambition can not be met and satisfied, but when analysing the characteristics of the city of Riga, it can be concluded that the inequality in the city is obvious. One person has the opportunity to develop and have a good rest in the locality of his own, while the other is deprived of this opportunity; then the question is why there is such an inequality. An example is Mezciems, where the number of pre-school educational establishments is smaller than in Skanste, where the number of population is 10 times smaller. Whereas, when researching cultural institutions in the neighbourhood, an incomprehensible spectacle appears; cultural institutions are not available in the larger localities of the city, but in Bukulti, which has 600 residents, there is a cultural center, but in Ziepniekkalns, which has 33 thousand residents, there is no cultural centre, the same spectacle also opens up in Purvciems. Brasa, where residents are three to four times fewer than in Purvciems and Ziepniekkalns, has four cultural institutions. Of course, within Riga you can go to nearby localities or the center, where there are almost a hundred of cultural institutions. However, in order the residents would have opportunity to develop and creatively improve in their locality, a cultural institution is often the place, where various events for children, adults and elderly people are organized, in order the resident could participate and feel comfortably in his/her locality and the city as a whole and he/she has the opportunity to attend some beautiful cultural and educational event and feel that he/she belongs to it.

Further, in this research, the general characteristics of the city, the structure and characteristics of the population will be dealt with. The local government budget will be explored and analysed to determine the impact of the resident on the sustainable urban economic development. 


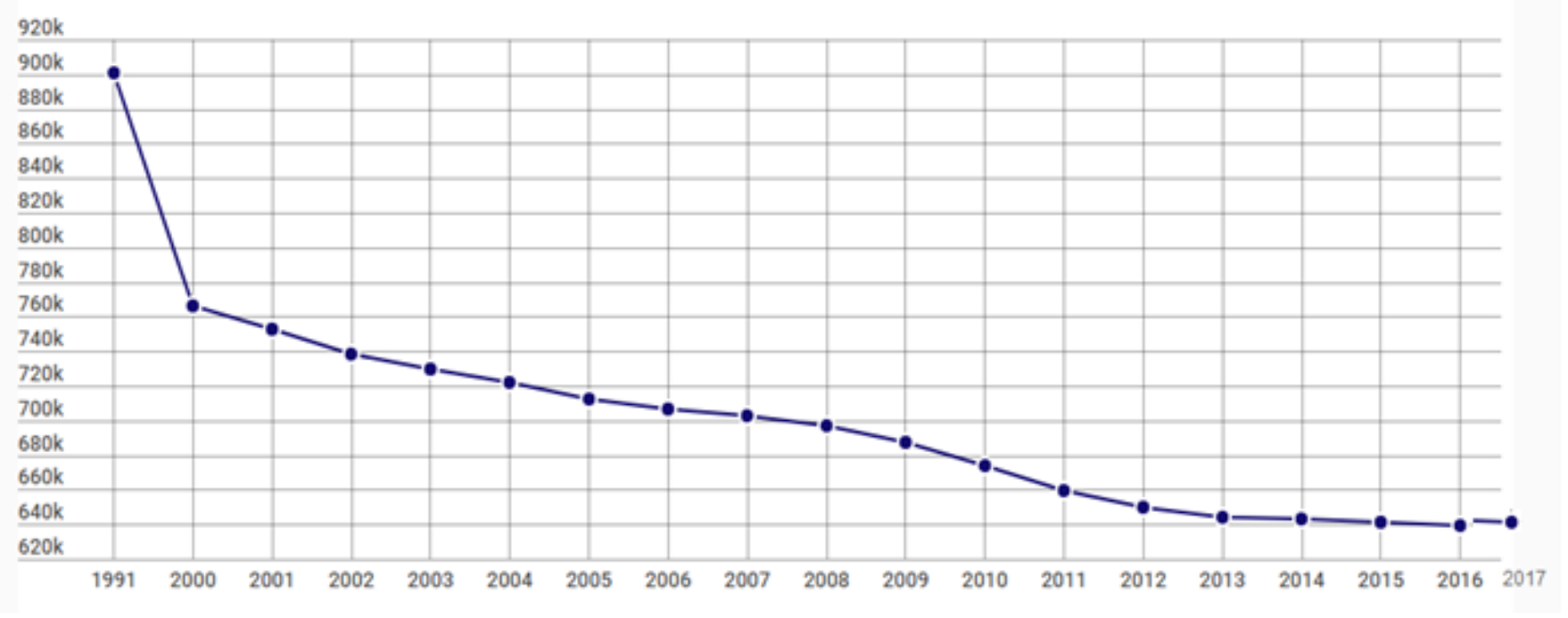

Figure. 1 The number of permanent residents in Riga Source: Central Statistical Office

Contrary to the generally accepted belief that Riga deprives the regions of the most workable and active residents, it must be admitted that, unfortunately, the statistics show a slightly different picture, as it is shown in Figure 1, since 1991 the number of population in the capital has decreased. Riga has not succeeded in stabilizing the number of its permanent residents, as from 2000 until 2017 their number has decreased by 16, $3 \%$ or from 766 thousand to not full 641 thousand. The same situation is abroad also. In Latvia, the number of population has decreased by $18 \%$ from 2000 until 2017, namely, from 2.38 to 1.95 million residents (Central Statistical Office). Looking at the neighbouring countries, the trend is different; in Tallinn, the number of population increased by $2 \%$, but in Vilnius, such a sharp shrinking of population is not taking place, there the number of population has decreased by $1.5 \%$ and now it has 534 thousand of residents. The positive point is that Riga is still the largest city of the Baltic cities, and in 2017, the statistics show that in 2017, the number of population is increased compared to 2016 (Central Statistical Office; The population of the counties of Lithuania). 


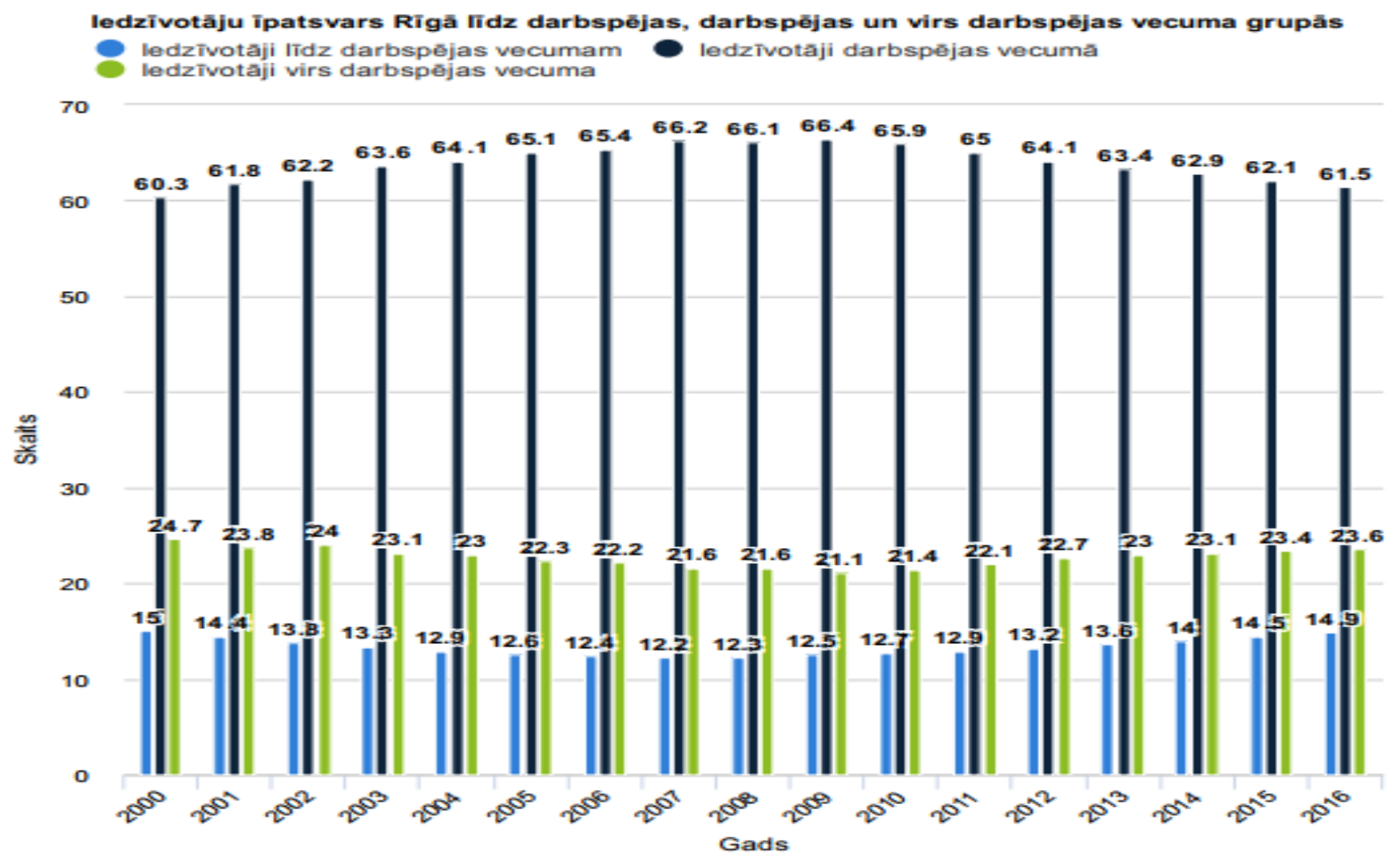

Figure. 2 Share of population in Riga Source: Statistics about Riga

Figure 2 shows the structure of Riga population, where it is clearly shown that the city has a sufficient number of able-bodied population, which is an essential indicator for promoting the sustainable urban economic development. However, their number is still unstable and volatile, as it is shown both in Figure 1 and Figure 2. Despite the fact that the number of able-bodied population is high enough, unfortunately, the number of employed people is falling faster than the number of able-bodied population (See Figure 2 and Figure 3), which is an important indicator, since the basic income of the Riga City budget is made up of personal income tax, which consists of on average $62 \%$ of the total revenues of the Riga City Municipality`s budget. 
ISSN 2345-0282 (online) http://jssidoi.org/jesi/

2017 Volume 5 Number 2 (December) http://doi.org/10.9770/jesi.2017.5.2(12)

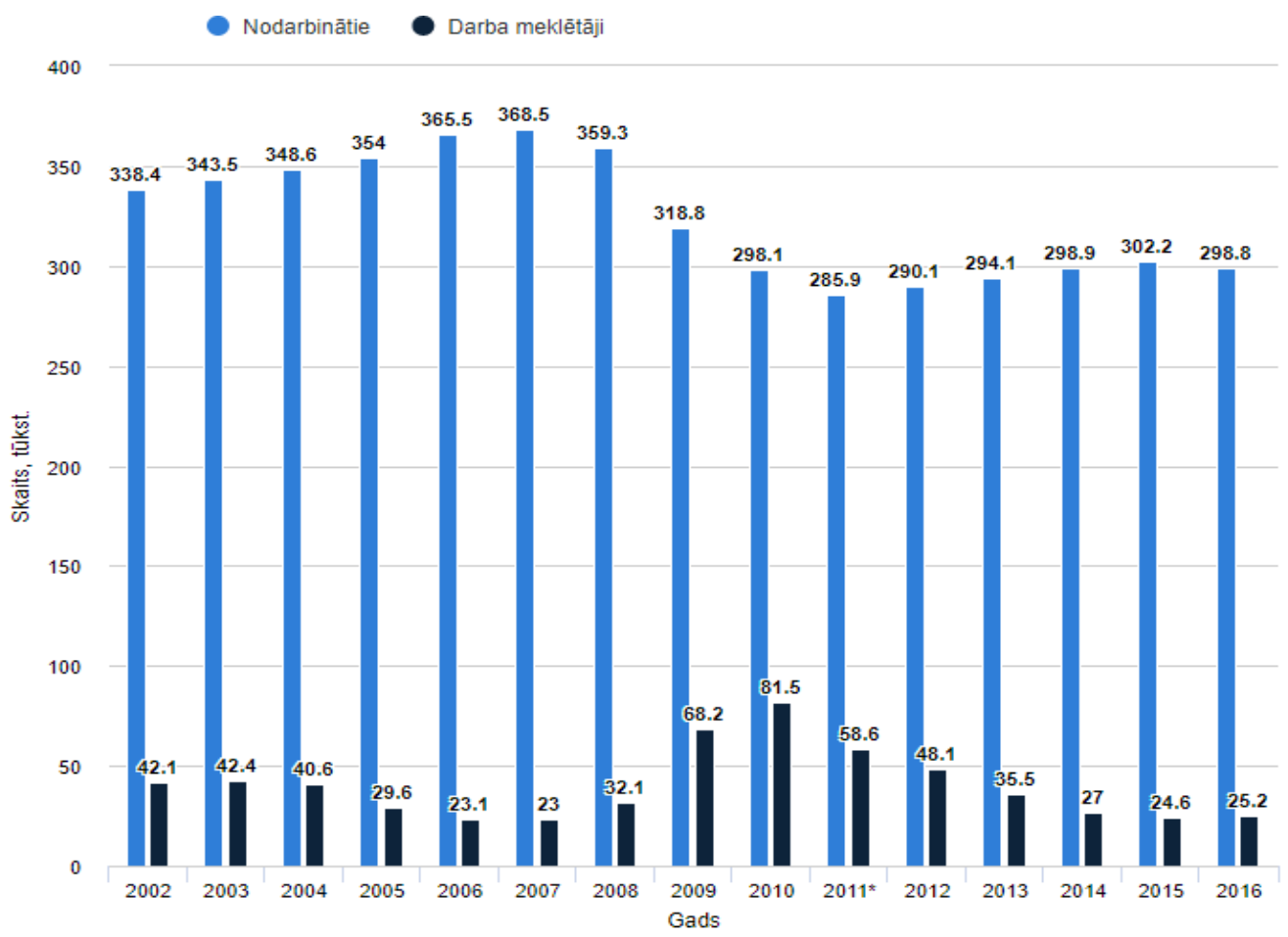

Figure 3. Job seekers and employed persons in Riga (thsd) Source: Statistics about Riga

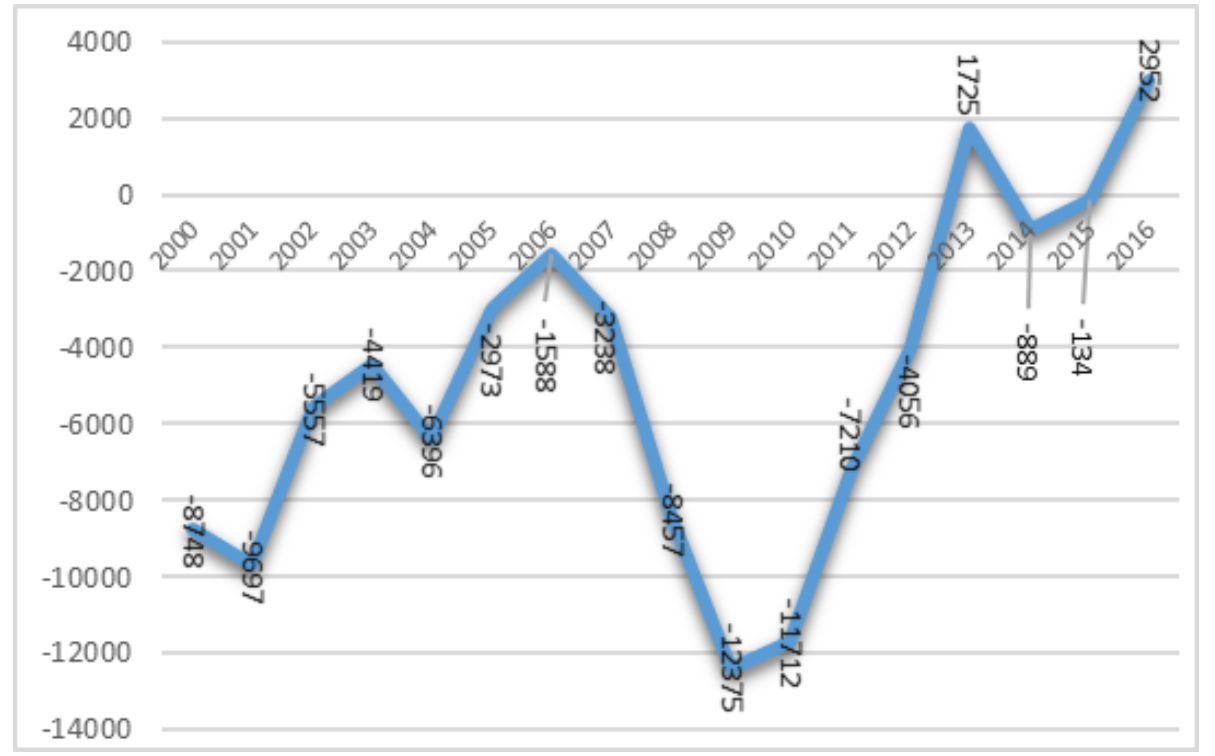

Figure. 4 Population migration balance in Riga

Source: Long-term migration of population in regions, republic cities and regions 
One of the reasons for the migration of population is the lack of affiliation to their place of residence and lack of cooperation with the municipality, as well as the resident does not feel himself/herself as a cooperation partner in the development of his/her city, despite the fact that the resident is the core of the city development in the city planning documents.

One of the important factors of the city development is the quality of development of city planning documents and their compliance with the goals set. Therefore, it is vital for the growth of cities of Latvia to continue the development and implementation of strategic planning and management documents both for the cities of republic significance and regional cities, based on analysis of indicators characterizing the socio-economic and territorial development of the cities (Grizans, Vanags 2010).

When analysing both the population survey and the city planning documents, it is, unfortunately, concluded that upon developing the city planning documents, the residents` wishes are not taken into account and their opinion is not heard, which also appears in the absence of cooperation.

Within the framework of the research, the population`s satisfaction with the city was viewed and the survey conducted by the SKDS (Market and Public Opinion Research Center) in 2014, which explicitly shows that residents of Riga enjoy public activities and are pleased to attend them, which is $69 \%$ of the respondents that also shows the need for cultural institutions. The survey also shows that the involvement of the population in the development and improvement of their locality has decreased by 50\% (compared the survey conducted in 2014 to 2010). As well as the author of the research, in March 2015, conducted a survey of residents of the largest localities of the city of Riga (Ziepniekkalns, Plavnieki, Purvciems, Kengarags un Imanta), as a result of which it was established that the city development took place not complying with the city planning documents, because the residents were not provided with equal living conditions; it becomes apparent in such way that in Kengarags there is only one children`s play area for nine courtyards. The mentioned situation in the management and planning of the city creates a sense of inequality in the residents. Consequently, it results in retroactive effect; the resident becomes abusive and does not want to participate in any activities related to the city development. All this also appears among the respondents and the sceptic attitudes of the residents towards the work of the local government and cooperation with it.

Not less important indicator is high prices of apartments in Riga, because, for example, in Ogre, Salaspils and Jurmala (Kauguri), apartment prices per square meter are lower by 30-50\% than in Riga both in the new projects market and the standard-type apartment market (Real Estate Market Overview).

If the cooperation is not improved and a sense of responsibility and affiliation to their living environment is not created in the population, then in the long run, a large part of the living fund will be exposed to the risk of degradation. Such current model and rate of the city development is not sustainable, i.e. it is not comfortable to live in such environment for neither present nor future generations, as most of the city, with such a development, will become a brownfield, and "Ghetto" localities will grow in number. Therefore, one should take an example from European countries where the main principle of development is to make the living environment more attractive, but not forgetting the state of environment, which is essential, because it is necessary to maintain an aesthetically pleasing environment around the living area, in order to have a resident's desire to return to his/her locality. In order to be sustainable, one must be able to think innovatively, thus, it is necessary to create innovative ideas for the further development of the city by attracting and working together with the society.

Given that Riga consists of 58 districts and has several thousand residents in each locality with the total population of 641 thousand, the main goal of the city of Riga should be to increase their number and keep the stay of the existing residents in the city, therefore it is important to observe the factors indicated in Figure 5, then the resident will be affiliated and feel comfortable so as not to think about changing the place of residence. 


\section{Physical}

well-being

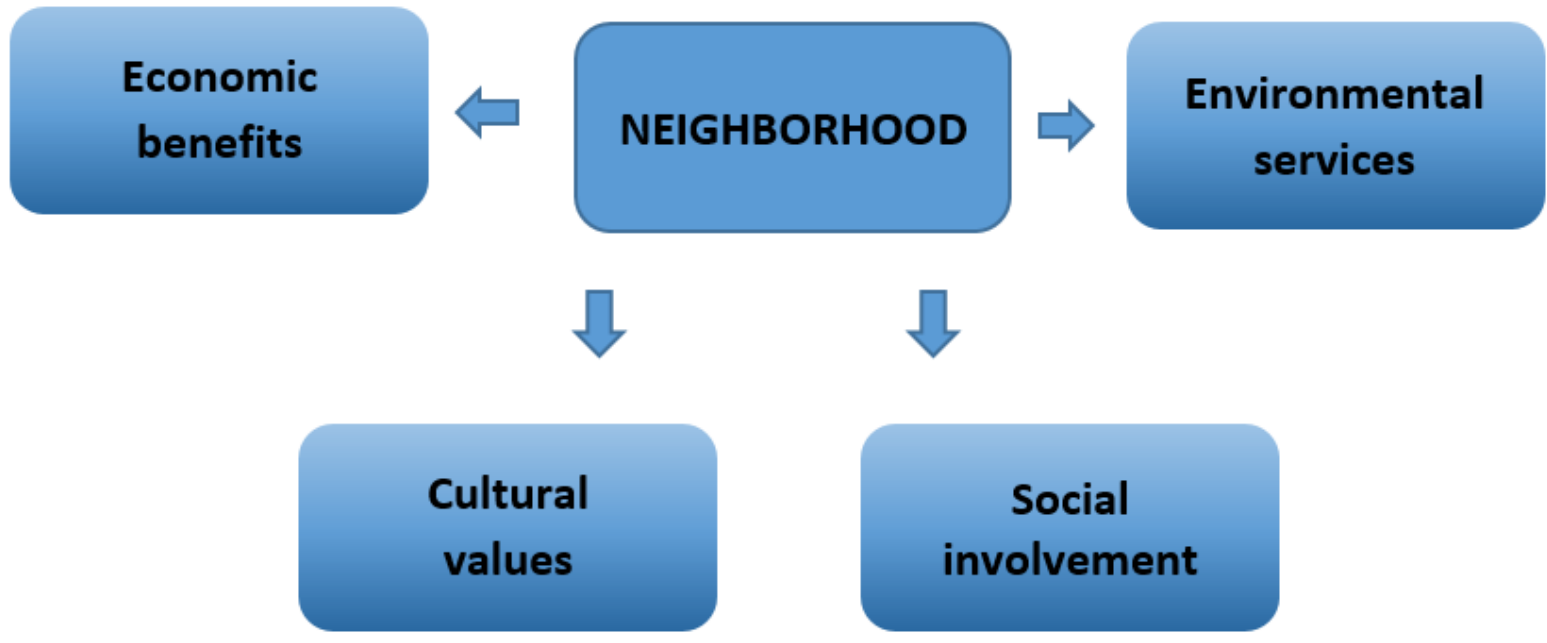

Figure 5. Contributions of a district to the city of Riga Source: developed by authors

Given that the city consists of localities, then, as Figure 5 shows, the image of the city of Riga and, in particular, of localities is influenced by five important and interconnected factors:

1. Economic benefits mean that a well-organized infrastructure in the locality, i.e. kindergartens, polyclinics, hobby groups, and sports clubs, and other activities, should be located in the locality. Also, developing the living environment in the locality, desire for living accommodation increases, hence the interest of investors in investing their funds in its development grows, which would also raise market prices of real estates.

2. Cultural values - the opportunity to develop in a cultural way, to visit the events organized by own locality and the city, to be informed of activities in nearby localities and also the opportunity to participate and develop.

3. Social engagement - the opportunity to participate in social life in his/her locality. To participate in the adjustment, improvement of his/her place of residence, to cooperate with the Riga Municipality and to participate in public deliberations on the development of his/her locality. 
4. Environmental services include the opportunity to enjoy your leisure time in an orderly environment, with persons being in the yard, exchanging views with the surrounding people and living in an orderly, safe and environmentally friendly environment.

5. Physical well-being includes free-to-use sports fields, cycling routes and various other activities to develop physically and mentally within the limits of your locality. Organization of various events for residents of the locality, bringing the locality closer together, and enhancing your affiliation to it.

Following all the five interconnected factors and all the four goals stipulated in the city development documents, which interact with each other and which are based on the sustainable urban economic development, and being based on the city`s pillars: society, urban environment and economy, and considering Rigans (residents of the city) as the center of the pillars, the resident will feel comfortably and necessary and belonging to his/her place of residence, creating a desire to stay and live there. Figure 6 shows the real situation in inner courtyards of the localities of the city of Riga, which in no way express the interest of the local government in welfare of residents at their place of residence. This situation in the localities of the city of Riga is not the only one, there are many and more dramatic. The inner courtyards indicates in Figure 6 are in the largest localities of the city of Riga (Ziepniekkalns and Kengarags), the situation is dramatic.

The sustainable development is defined in a wide variety of ways, and its definition is dealt with very differently, because the process of sustainable development is topical throughout the lifetime of mankind and the concept is gaining in popularity. For the first time, the concept "sustainability” (Nachhaltigkeit) was used in 1713 in an article on the sustainable use of forests: "You can take from the forest as much as it can grow" (Hans Carl von Carlowitz, 1713).

It should be remembered that the city of Riga has also a social function and it can promote the communication and interaction among the people that will promote the emergence of new contacts that can form founding of new associations of population, which gives more motivation to fight for their desire to improve the environment at their place of residence, in order Rigans have the opportunity to spend their time comfortably that will also promote cultural functions, strengthening the resident's identity and sense of affiliation to his/her place of residence. It should be remembered that the localities serve as essential symbols for shaping the city`s image and are important cultural heritage for the future generations, therefore their development needs to be given special attention and the principles and priorities of planning documents of the future city should be considered in order to make the written coincide with the done. 

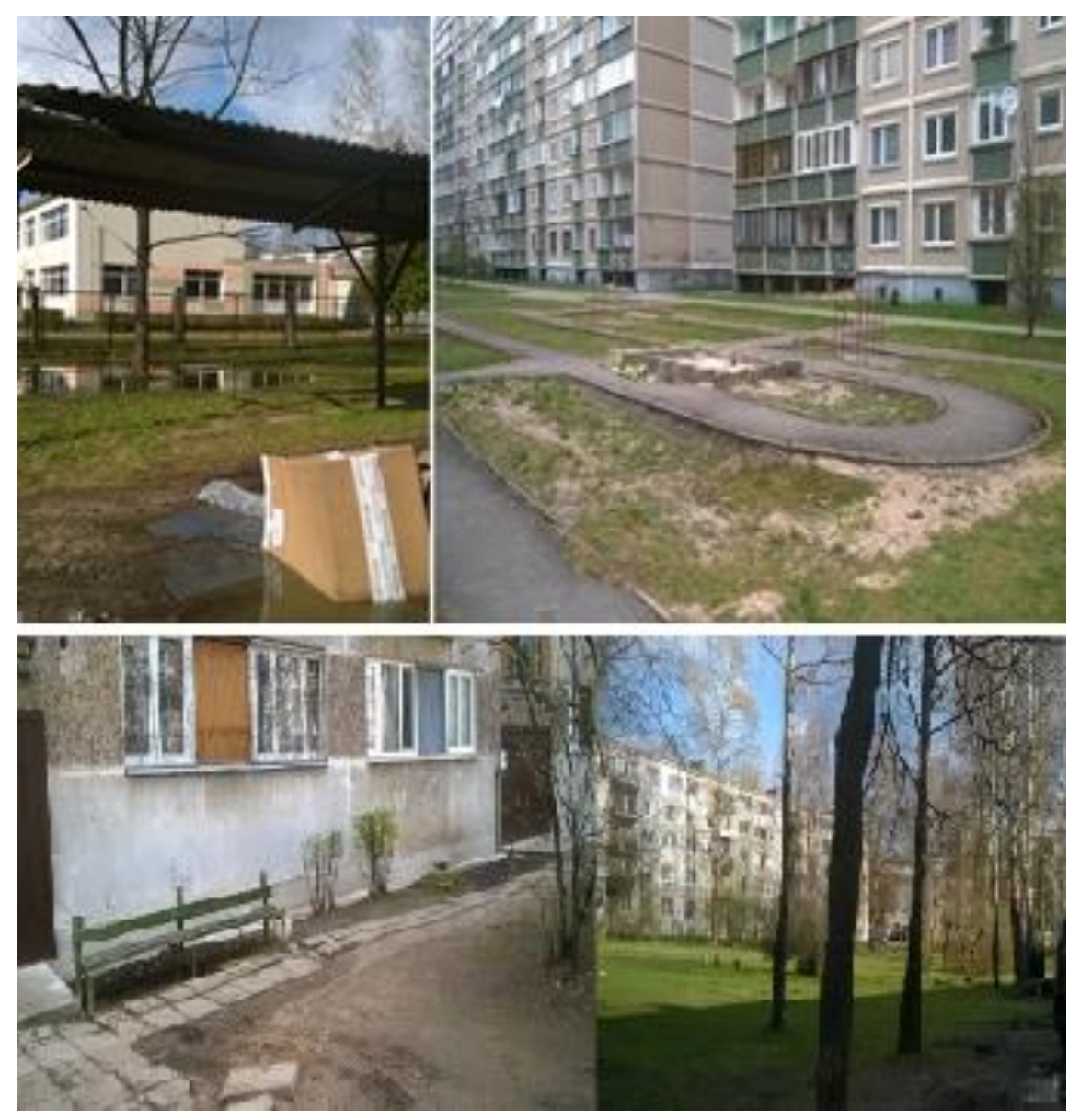

Figure 6. Inner courtyard of the city of Riga Source: from the author`s own archive

It must be admitted that a pleasant and safe locality is one of the most important factors for ensuring social welfare of the society. The pleasant surroundings give rise to a desire of people to preserve all that and continue to stay there.

Involvement of residents in forming the locality system, i.e. in the development of the city, is one of the instruments for developing and improving Riga urban environment. The municipality can implement and manage the sustainable urban environment development only if there are competent and Professional workers who are performing the basic work of urban development, because at the moment things seem to be chaotic, without a concrete plan and strategy and future outlook. Therefore, the active participation of residents in the work of local governments can both directly and positively influence the sustainable development of the city and indirectly, as when the residents feel more satisfied with the work of the local government and trust in it, there is a higher motivation to live and work in the particular area. Therefore, one should agree with the written that urban development in Latvia is possible not in a rivalry but in a partnership (Grizans; Vanags 2010).

The next part of the research will assess the impact of a resident on the sustainable urban economic development. 


\section{Assessment of the impact of a resident on the sustainable economic development}

One of the main factors for the sustainable urban economic development is the number of population, which in Riga is large enough to compete and provide economic benefits to the Riga Municipality in the form of budget revenue. Also, not less important factor is the number of able-bodied residents, which at the moment on average is $63 \%$ of the total population of the city.

In the future, the Riga Municipality should look through how to preserve and maintain the youth`s routine and stay in the agglomeration of Riga and not to migrate to foreign countries and other cities, and not only to set goals and objectives on paper, but also to reflect all this in reality in the labor market.

In 2016, the Ministry of Education and Science commissioned LLC "Excolo Latvia" to carry out a research on "The involvement of the Latvian youth in entrepreneurship". The research showed that the Riga City Council had launched several activities and projects for attracting young people to commence their own business and stay in the national labor market, for example, the City Development Department, in cooperation with JSC SWEDBANK, organized a grant program "Take-off", within which the young entrepreneurs of Riga (including majors) were entitled to receive financial support for the commencement or development of their business. It also participates in a grant program "Promotion of employment of the social exclusion risk groups in Riga" , the project name is Take-off, the aim of which is to stimulate the development of new, innovative entrepreneurs and to promote the innovative development of existing enterprises in the administrative territory of Riga, where the second activity is promoting the employment of the social exclusion risk groups in Riga, the aim of which is to stimulate, launch or develop and implement the development of the sustainable development of societies and foundations or entrepreneurs in order to ensure employment opportunities, incl. creating new or improving existing jobs for target groups at risk of social exclusion (Latvian youth involvement in business).

As well as, the Department of Education, Culture and Sports of the Riga City Council organizes several events to support the involvement of young people in a number of entrepreneurial activities, such as entrepreneurial training for young people and youth groups "YES", whose aim is to strengthen the youth's NGO sector in Riga and contribute to the sustainability of organizations, to create a safe environment, in which young people are able to create their own jobs by monetizing ideas. The second activity is a project "My generation in the labor market" (URBACT II Program), the aim of which is to promote the employment of young people in a changing labor market, in particular by promoting entrepreneurship skills and attitudes (Latvian youth involvement in business).

The research shows that young people of Latvia at school age are very interested in entrepreneurship, but by age growing, this interest significantly diminishes and more interest is in being an entrepreneur/self-employed on their own, rather than creating larger entrepreneurship and employing others. Also, according to young people, the image and culture of entrepreneurship and its environment are, in general, not positive, as the image of enterprise is often associated with unfair business practices, the widespread image of public institutions as a threat to entrepreneurship as well as the low level of social capital in Latvia - distrust in others, fear of sharing ideas, lack of skills of working in a team, fear of failures (Latvian youth involvement in business).

The mentioned research shows that the Riga City`s Municipality, in cooperation with the private sector, organizes activities for attracting young people to the development of entrepreneurship and integration into the labor market, but, unfortunately, the analysis of the research shows that young people feel insecure due to the situation of the tax and common business environment existing in our country. Therefore, this issue needs to be raised at the national level, which is currently indolent, because integration of young people into the labor market is problematic, as the desires do not coincide with the offer. This also shows the lack of cooperation in developing strategic documents of this kind. 
Table 1 shows a common characteristics of the city of Riga, the indicators emphasize the importance of the city`s resident both in the economic development of the city and in the sustainable urban development, as without the support of residents and professionalism of the municipality, the sustainable existence is not possible, therefore it is essential that there is cooperation between both parties, since one party gives resources, and the other party must be able to manage them effectively. Therefore, mutual trust and cooperation is important for the sustainable development of the city and state.

Table 1. Economic characterization of residents of Riga

Source: Residential district statistics, Residents and social processe, Statistics about Riga

\begin{tabular}{|c|c|c|c|c|c|c|c|c|c|c|}
\hline & 2007 & 2008 & 2009 & 2010 & 2011 & 2012 & 2013 & 2014 & 2015 & 2016 \\
\hline $\begin{array}{l}\text { Population } \\
\text { (thsd) }\end{array}$ & 706,6 & 705,6 & 697,3 & 687,4 & 673,4 & 649,9 & 643,6 & 643,4 & 641 & 639,6 \\
\hline $\begin{array}{l}\text { Working-age } \\
\text { population } \\
(15-64 \text { years } \\
\text { old) }(\%)\end{array}$ & 66,2 & 66,1 & 66,4 & 65,9 & 65,0 & 64,1 & 63,4 & 62,9 & 62,1 & 61,5 \\
\hline $\begin{array}{l}\text { Number of } \\
\text { employed } \\
\text { (thsd) }\end{array}$ & 368,5 & 359,3 & 318,8 & 298,1 & 285,9 & 290,1 & 294,1 & 298,9 & 302,2 & 298,8 \\
\hline $\begin{array}{l}\text { Personal } \\
\text { income tax } \\
\text { (milj.) }\end{array}$ & 414,06 & 504,12 & 350,03 & 356,29 & 362,83 & 380,48 & 406,94 & 450,05 & 459,78 & 507,06 \\
\hline
\end{tabular}

So, Table 1 shows that, despite of the fact that the number of population has decreased, the local government has considerably increased amount of personal income tax in the budget; these indicators also show an increase in income of the population. In 2016, an employed resident of the city pays 6193.7 euro into the Riga Municipality`s budget from personal income tax. Also, the Table 1 clearly shows that as a result of the decrease in the number of population the number of able-bodied residents is decreasing, which shows that exactly able-bodied residents migrate from Riga, which brings economic contribution to the city of Riga. Today, in Riga, unemployment is $3.6 \%$, which is lower compared to $2016(5 \%)$ and shows that, nevertheless, the city of Riga is attractive its residents both economically and socially, because according to the data of the Central Statistics Bureau, the number of population in 2017 is at the same level as in 2015, but the number of population is still close to figures of 2007.

It must be admitted that, in general, the city of Riga is changing and urban planning is gradually taking place thoughtfully, but the "monologue" situation, and not the "dialogue" situation, is still felt, because cooperation is still of low capacity. Attending the conference on the future large-scale changes in the Skanste locality, the participation and activity of the population is low, the number of participants in the conference was small and, 
during discussion, the lack of attention of planners to the shortcomings in territory development planning reasonably expressed by entrepreneurs and residents. This case also shows that it is not for nothing that Rigans have sceptical attitude to the ongoing system in Riga planning, because the residents believe that their opinions will not be taken into account.

Therefore, doubts arise about the Riga Municipality`s understanding of the sustainability and economic growth of the city, as it is important to motivate the local patriotic spirit in the population, providing the residents with a qualitative, comfortable, pleasant and environmentally friendly living environment, in order to enable the resident to economically grow and develop instead of degrading himself/herself and degrading surrounding medium that is happening at the moment.

\section{Conclusions}

The resident of Riga is an important part of the city, which is also a fascinator of and participant in the sustainable economic development. Therefore, it is important to promote local patriotism in the population as well as cooperation with the local government, which will increase the trust and willingness of the resident to participate in the development of his/her living environment.

As a result of the research, it can be concluded that the city management lacks professional experience and skills to handle and efficiently manage existing resources, as the implemented does not coincide with the desires of the population and the overall image of the city.

It is important that the main pillar of the city`s development is the opportunity for the residents to live in a qualitative living environment with a diverse and lively outdoor space, feel safe while staying and moving in the locality, have an advanced infrastructure and, of course, have a sense of affiliation to his/her locality and city. To feel needed for his/her city.

Good urban planning and management practices also show a level of welfare both in the population and the urban environment. A high quality living environment in an attractive locality is one of the main conditions for the sustainable development and labor force attraction to the city.

Given that the impact of the resident on the sustainable urban economic development is important, as his/her contribution to the city`s municipality makes up $63 \%$ of the total budget revenue, it is important to save the residents in their city and attract new residents. In a developed city, a developed society.

Active participation of residents in the work of local governments can directly positively influence the development of the city, as well as indirectly - when residents feel more satisfied with the work of the local government and trust in it, there is a higher motivation to live and work in the particular territory. Therefore, it must be said that the development of cities in Latvia is possible not in a rivalry but in a partnership.

\section{References}

Area, population density and the number of permanent residents in regions, republic cities and regions at the beginning of the year. [Electronic resource]// Central Statistical Office website. Resource viewed $2017 \quad 10 \quad$ Apr. http://data.csb.gov.lv/pxweb/lv/Sociala/Sociala_ikgad_iedz_iedzskaits/IS0010.px/?rxid=09cbdccf-2334-4466-bdf7-0051bad1decd

Bakule, I., Siksna, A. 2009. Riga outside the fortifications. The planned construction and redevelopment of the city from the 17th century to the First World War. Riga, Neptuns 247 p. 
ENTREPRENEURSHIP AND SUSTAINABILITY ISSUES

ISSN 2345-0282 (online) http://jssidoi.org/jesi/

2017 Volume 5 Number 2 (December)

http://doi.org/10.9770/jesi.2017.5.2(12)

Bilan, Y.; Zos-Kior, M.; Nitsenko, V.; Sinelnikau, U.; Ilin, V. 2017. Social component in sustainable management of land resources, Journal of Security and Sustainability Issues 7(2): 287-300. https://doi.org/https://doi.org/10.9770/jssi.2017.7.2(9)

Grizans, J.; Vanags J. 2010. The aspects of planning and managing the sustainable development of cities, Economics and Business. Economy: Theory and Practice 20: 51-58 https://webcache.googleusercontent.com/search?q=cache:V74QUV7Kn8kJ:https://ortus.rtu.lv/science/lv/publications/9591/fulltext+\&cd=3 $\underline{\& h l=l v \& c t=c \operatorname{lnk} \& g l=l v}$

History of Riga. [Electronic resource]// Riga planning region websiteResource viewed $2017 \quad 14 \quad$ Mar. http://www.rpr.gov.lv/pub/index.php?id=79

Kalnina-Lukasevica Z. 2013) The development of regions in Latvia - a model for planning and evaluating regional economic development. Doctoral Thesis. Riga, LU. $280 \quad$ p. $\quad$ http://dspace.lu.lv/dspace/bitstream/handle/7/4740/24554Zanda_Kalnina_Lukasevica_2013_\%282\%29.pdf?sequence=1\&isAllowed=y

Kendiukhov, I.; Tvaronavičienè, M. 2017. Managing innovations in sustainable economic growth, Marketing and Management of Innovation http://dx.doi.org/10.21272/mmi.2017.3-03

Kreituse, I.; Janaitis, G.; Švanka E. 2009. Past year Latvia 1945-1990. Publishing House ABC. 168 p.

Lincényi, M.; Fabuš, M. 2017. Economic trends of business actors on daily newspaper market: case of the Slovak Republic, Entrepreneurship and Sustainability Issues 5(1): 91-104. https://doi.org/10.9770/jesi.2017.5.1(7)

Long-term migration of population in regions, republic cities and regions. [Electronic resource]// Central Statistical Office website Resource viewed 201710 Apr. http://data.csb.gov.lv/pxweb/lv/Sociala/Sociala_ikgad_iedz_migr/IB0100.px/?rxid=562c2205-ba57$\underline{4130-b 63 a-6991 f 49 a b 6 f e}$

Main demographic indicators. [Electronic resource]// Central Statistical Office website Resource viewed $2017 \quad 10$ Apr. http://pub.stat.ee/px-

web.2001/I_Databas/Population/01Population_indicators_and_composition/02Main_demographic_indicators/02Main_demographic_indica tors.asp

Menshikov, V.; Volkova, O.; Stukalo, N.; Simakhova, A. 2017. Social economy as a tool to ensure national security, Journal of Security and Sustainability Issues 7(2): 211-231. https://doi.org/https://doi.org/10.9770/jssi.2017.7.2(4)

Real Estate Market Overview. [Electronic resource]// Latio website Resource viewed 201724 May. http://latio.lv/lv/pakalpojumi/tirgus$\underline{\text { analize }}$

Residential district statistics. [Electronic resource]// The homepage of the neighborhood Resource viewed 20178. May http://www.apkaimes.lv/stat/

Residents and social processes. [Electronic resource]// Central Statistical Office website Resource viewed 201710 Apr. http://data.csb.gov.lv/pxweb/lv/Sociala/Sociala_ikgad_iedz_iedzskaits/?tablelist=true\&rxid=09cbdccf-2334-4466-bdf7-0051bad1decd

Riga Development Program 2014-2020. [Electronic resource]// Riga City Council City Development Department - Resource viewed 2017. 5 May http://rdpad.lv/uploads/rpap/Attistibas_programmas.pdf

Riga Sustainable Development Strategy till 2030. [Electronic resource]// Riga City Council City Development Department Resource viewed 2017 5. May http://rdpad.lv/uploads/2030/Strategija_2014-2030.pdf

Rubins, J. 2004. Riga Housing Fund in the 20th Century. Riga: Jumava 104 pp.

Statistics about Riga. [Electronic resource]/SUS website - Resource viewed 2017 28.Apr. http://www.sus.lv/lv/statistika

Štiglic, D. 2017. Towards security through economic policy: a Baldwin's approach, Journal of Security and Sustainability Issues 7(1): 5565. https://doi.org/10.9770/jssi.2017.7.1(6)

The final study report "Latvian youth involvement in business." [Electronic resource]// Education and Science Ministry website Resource viewed

2017

12 Apr. 
ENTREPRENEURSHIP AND SUSTAINABILITY ISSUES

ISSN 2345-0282 (online) http://jssidoi.org/jesi/

2017 Volume 5 Number 2 (December)

http://doi.org/10.9770/jesi.2017.5.2(12)

http://www.izm.gov.lv/images/statistika/petijumi/jaunatne/IZM_Jaunie\%C5\%A1i_uz\%C5\%86\%C4\%93m\%C4\%93jdarb\%C4\%ABb\%C4 \%81_2016_Excolo_Latvia.pdf

The population of the counties of Lithuania according to census results and latest official estimates. [Electronic resource] Resource viewed 201710 Apr. https://www.citypopulation.de/Lithuania-Cities.html

Tvaronavičienė, M., Razminienè, K. 2017. Towards competitive regional development through clusters: approaches to their performance evaluation, Journal of Competitiveness 9(4): 133 - 147. http://dx.doi.org/10.7441/joc.2017.04.09

Tvaronavičienè, M; Gatautis, R. 2017. Peculiarities of income distribution in selected countries. Economics and Sociology, 10(4), 113-123. http://dx.doi.org/10.14254/2071-789X.2017/10-4/9

Zemlickiene, V.; Mačiulis, A.; Tvaronavičienè, M. 2017. Factors impacting the commercial potential of technologies: expert approach, Technological and Economic Development of Economy, 23(2): 410-427. http://dx.doi.org/10.3846/20294913.2016.1271061

Inesa PAVLOVA, Mg.oec. 2015 professional Master in Economics. From 2007 until now Administrative Officer of Riga Technical University and from 2016 until now scientific assistant of Riga Technical University, Faculty of Engineering Economics and Management. Obtained Professional Bachelor degree in Public Law from Latvian Police Academy (2008). Professional Bachelor degree in Customs and Tax Administration obtained from Riga Technical University, Faculty of Engineering Economics and Management (2013). From 2016 until now, study Doctoral at Riga Technical University. Division of Continuing Education of Riga Technical University.

Maija SENFELDE, Dr.oec. Riga Technical University, Faculty of Engineering Economics and Management, Department of Territorial Development Governance and Urban Economics, Head of the Department and Professor.

Copyright (C) 2017 by author(s) and VsI Entrepreneurship and Sustainability Center This work is licensed under the Creative Commons Attribution International License (CC BY). http://creativecommons.org/licenses/by/4.0/

cC) (i) Open Access

